\title{
EFFECT OF GAMMA IRRADIATION ON THE MICROBIAL LOAD, CHEMICAL AND SENSORY PROPERTIES OF GOAT MEAT
}

\author{
M. Al-BACHIR* and R. ZeINOU \\ Radiation Technology Department, Syrian Atomic Energy Commission, P.O. Box: 6091, Damascus. Syria.
}

(Received: 11 November 2012; accepted: 13 January 2013)

\begin{abstract}
The present study was undertaken to assess the effects of gamma irradiation $(0,2,4$, and $6 \mathrm{kGy})$ on microbial, chemical, and sensory values of Jabaly Syrian goat meat during storage at $4{ }^{\circ} \mathrm{C}$ for $1,3,4$, and 5 weeks. Irradiation was effective in reducing the microbial load and increasing the shelf-life of goat meat. The radiation doses required to reduce the microorganisms by 90 percent $\left(\mathrm{D}_{10}\right)$ in goat meat were 294 and 400 Gy for Salmonella and E. coli, respectively. The main fatty acids identified from the goat meat were oleic, stearic, and palmitic acids. No significant differences were observed in moisture, crude protein, crude fat, ash, $\mathrm{pH}$ value, fatty acids, total acidity, volatile basic nitrogen, and sensory properties (texture, flavour, colour, and taste) of irradiated and non-irradiated goat meat. Lipid peroxidation measured in terms of thiobarbituric acid-reactive substances (TBARS) increased on irradiation and chilled storage. Sensory evaluation showed no significant differences between irradiated and non-irradiated goat meat.
\end{abstract}

Keywords: goat meat, irradiation, microbial load, refrigeration, sensory evaluation

Goat meat (Chevon) is an important protein source throughout the world, especially in developing countries (BISwAS et al., 2007). Chevon is also attractive to health conscious consumers due to its lower total fat and higher unsaturated fatty acid levels compared to other traditional red meats (LEE et al., 2008a).

Radiation processing of meat is recognized as a safe and effective method among the existing technologies for meat preservation (AL-BACHIR, 2005). Radiation processing of fresh meat extends the shelf-life and protects the consumer against pathogenic bacteria (AL-BACHIR \& ZEINOU, 2009). Even though irradiation is a prospective technology, its application causes physico-chemical and biochemical changes that affect the nutritional value and sensory characteristics of irradiated food (SoHN et al., 2009). The advantages of irradiation in controlling microorganisms and improving the shelf-life of different kinds of red meat, such as fresh beef (CHEN et al., 2007), lamb meat (KANATT et al., 2007), and camel meat (AL-BACHIR \& ZeINOU, 2009), are well known, but there is only limited information in the literature on the effect of ionizing irradiation on the safety and shelf-life of goat meat (Modi et al., 2008). Knowledge of meat yield and quality of indigenous goats is limited. Published data on the chemical composition, nutritional, and sensory attributes of pure goat meat is scarce and little information is available on using irradiation to improve goat meat quality and shelf-life. Therefore, the objective of this study was to investigate the effect of using gamma irradiation on the shelf-life and the sensory and chemical properties of goat meat.

\footnotetext{
* To whom correspondence should be addressed.

Phone: 00963-11-2132580; fax: 00963-11-6112289; e-mail: ascientific@aec.org.sy
} 


\section{Materials and methods}

\subsection{Materials}

The fresh meat of approximately 6 months old and $25 \mathrm{~kg}$ male kid of Jabali goat was used in this work. Meat was ground through a 2-4 mm grinder plate, and $200 \mathrm{~g}$ of meat was transferred into polyethylene bags. Each bag is considered as replicate.

\subsection{Irradiation and analysis performed after processing}

Samples from packed goat meat were exposed to gamma radiation at doses of $0,2,4$, and 6 $\mathrm{kGy}$ in $\mathrm{a}^{60}$ Co package irradiator (dose rate $9 \mathrm{kGy} \mathrm{h}^{-1}$ ). The irradiation was performed at room temperature $\left(15-20^{\circ} \mathrm{C}\right)$. The absorbed dose was determined using alcoholic chlorobenzene dosimeter by the measurement of chloride ions or hydrogen ions by oscillotitrator (OK302/2, Radelkisz, Budapest, Hungary). Meat samples were stored at $1-4{ }^{\circ} \mathrm{C}$. Microbiological and chemical analyses were performed after $0,1,3,4$, and 5 weeks of storage. Sensory evaluation and proximate analysis were done two days after irradiation.

\subsection{Microbiological evaluation}

Three replicates from each treatment, irradiated and non-irradiated, were aseptically opened and decimal serial dilution was prepared from $10 \mathrm{~g}$ of each according to the standard methods (A.O.A.C., 1990). Nutrient agar (Oxoid, CM 325, UK) was used for the determination of total (mesophilic aerobic) plate counts (TPCs) (48 h incubation at $30{ }^{\circ} \mathrm{C}$ ). A cut-off value of $10^{7} \mathrm{CFU} \mathrm{g}^{-1}$ for TPCs (AL-BACHIR \& ZEINOU, 2009) was used for the unacceptable samples. Total coliforms were determined on Violet Red Bile Agar (VRBA) (Oxoid, CM 485, UK) incubated at $37{ }^{\circ} \mathrm{C}$ for $48 \mathrm{~h}$.

To determine the survival curves, the meat was artificially inoculated by thoroughly mixing it with pure cultures of Salmonella sp. and Escherichia coli. The survival curve was estimated from the number of survivors at irradiation doses of $0.2,0.4,0.6,0.8$, and $1.0 \mathrm{kGy}$. The survival numbers of Salmonella sp. was determined by plate counting on Xylose Lysine Desoxycholate Agar (XLD) (Biolife, 402206, Italy) and the survival numbers of E. coli was determined by plate counting on Eosin Methylene Blue Agar (EMBA) (Oxoid, CM 69, UK) after 2 days of incubation at $37^{\circ} \mathrm{C}$.

\subsection{Chemical and physical analysis}

Each sample was homogenized and analysed in triplicates to determine moisture (drying for $6 \mathrm{~h}$ at $105^{\circ} \mathrm{C}$ ), crude fat (as extractable component in Soxhlet apparatus, Glas-Col, U.S.A.), and crude protein (as Kjeldahl nitrogen) contents using standard methods (A.O.A.C., 1990). The concentrations of the major trace elements were determined using instrumental neutron activation analysis (PARRY, 1991). pH values of the suspensions of goat meat were determined using an HI $8521 \mathrm{pH}$ meter (Hanna Instruments, Woonsocket, RI, USA). Water activity was determined using reference solutions (AL-BACHIR \& ZEINOU, 2009).

1.4.1. Total acidity and lipid oxidation. The total acidity was obtained by a direct titration with $(0.1 \mathrm{~N}) \mathrm{NaOH}$ and phenolphthalein as indicator (EGAN et al., 1981). The total acidity was calculated as $\mathrm{ml}$ of $(0.1 \mathrm{~N}) \mathrm{NaOH}=0.0090 \mathrm{~g}$ lactic acid. Thiobarbituric Acid (TBA) values were determined and expressed as mg malonaldehyde (MDA) per $1 \mathrm{~kg}$ goat meat (ALBACHIR, 2005). 
1.4.2. Fatty acids (FA) determination. The lipid fraction of goat meat samples was extracted and FA methyl esters (FAME) were prepared (AL-BACHIR \& ZEINOU, 2009). The FA profile was determined by gas chromatography in a GC-17 A Shimadzu chromatograph (Shimadzu Corp., Kyoto, Japan) equipped with a flame ionization detector and a capillary column (CBP20-S25-050, Shimadzu, Australia). The selected chromatographic conditions were: oven temperature $190{ }^{\circ} \mathrm{C}$; detector temperature $250{ }^{\circ} \mathrm{C}$; injector temperature $220{ }^{\circ} \mathrm{C}$; $\mathrm{N}_{2}$ was used as a carrier gas with split ratio 29:1, the sample volume injected was $1 \mu \mathrm{l}$. Peak areas were integrated and converted to FA percentages (direct area normalization) by means of the CLASS-VP 4.3 program (Shimadzu Scientific Instruments, Inc., Columbia, MD). The FA identification was carried out by retention times and by addition of standards.

1.4.3. Total volatile basic nitrogen (VBN). Total volatile basic nitrogen in the sample in terms of mg VBN per kg goat meat (ppm) was determined (AL-BACHIR, 2005).

\subsection{Sensory evaluation}

The sensorial criteria, especially the taste, odour, colour, and texture of the irradiated and non-irradiated goat meat were evaluated by untrained panellists. All goat meats were tasted by 25 people. Before testing, all samples of meat were fried in fat for $5 \mathrm{~min}$ without spices or salts. Each member independently evaluated the meat for taste, odour, colour, and texture on a 5-point hedonic scale (1: extremely poor; 2: poor; 3: acceptable; 4: good; 5: excellent), according to AL-BACHIR and ZeINOU (2009).

\subsection{Statistical analysis}

The four treatments were distributed in a completely randomized design with three replicates. Data were subjected to the analysis of variance test (ANOVA) using the SUPERANOVA computer package (Abacus Concepts Inc, Berkeley, CA, USA; 1998). A separation test on treatment means was conducted using Fisher's least significant differences (LSD) methods (SNEDECOR \& Cochran, 1988) at 95\% confidence level. $\mathrm{D}_{10}$ values were calculated using Cricket graph computer package (40 Valley Stream Parkway Malvern, PA 19355, 1986/87/88 Cricket Software, Copyright, Version 1.3).

\section{Results and discussion}

\subsection{Chemical composition}

Proximate compositions of goat meat including moisture, crude protein, crude fat, ash, and $\mathrm{pH}$ value are presented in Table 1 . The water activity value for goat meat was 0.92 at $24{ }^{\circ} \mathrm{C}$. The amount of macro elements in goat meat were: $\mathrm{Ca} 0.24 \mathrm{~g} \mathrm{~kg}^{-1}, \mathrm{Na} 2.23 \mathrm{~g} \mathrm{~kg}^{-1}, \mathrm{~K} 10.31$ $\mathrm{g} \mathrm{kg}^{-1}$, and $\mathrm{Mg} 0.60 \mathrm{~g} \mathrm{~kg}^{-1}$, and the amount of micro element were: Fe 96 part per million (ppm), Zn 135 ppm, Br 11 ppm, Rb 13 ppm, Cr 1.2 ppm, Cu 3.8 ppm, Al 1.9 ppm, As 0.04 ppm, Co $0.01 \mathrm{ppm}$, Se $0.49 \mathrm{ppm}$, Ce $0.07 \mathrm{ppm}$, and Cs $0.01 \mathrm{ppm}$. In general, the moisture, protein, fat, and ash contents in goat meat ranged from $68 \%$ to $77 \%, 19 \%$ to $23 \%, 3.5 \%$ to $7.5 \%$, and 1.0 to $1.5 \%$, respectively (LEE et al., 2008a; 2008b). Therefore, our results are in agreement with previous references. No significant differences in moisture, protein, and fat contents of goat meat were observed due to irradiation. Similar observations on camel meat treated with 2, 4, and $6 \mathrm{kGy}$ doses of gamma irradiation were reported by others (AL-BACHIR \& ZEINOU, 2009). 
Table 1. Effect of gamma irradiation on moisture, dry matter, crude protein, crude fat, and ash contents $(\%)$ of goat meat

\begin{tabular}{lccccc}
\hline Treatment & Moisture & Crude protein & Crude fat & Ash & $\mathrm{pH}$ \\
\hline $0 \mathrm{kGy}$ & $71.43 \pm 1.24$ & $19.58 \pm 0.10$ & $5.75 \pm 0.93$ & $1.14 \pm 0.02$ & $5.65 \pm 0.21$ \\
$2 \mathrm{kGy}$ & $72.78 \pm 1.79$ & $21.15 \pm 0.28$ & $6.77 \pm 1.17$ & $1.03 \pm 0.08$ & $5.64 \pm 0.05$ \\
$4 \mathrm{kGy}$ & $69.16 \pm 1.25$ & $21.25 \pm 0.25$ & $7.36 \pm 0.43$ & $1.15 \pm 0.20$ & $5.59 \pm 0.02$ \\
$6 \mathrm{kGy}$ & $73.12 \pm 2.92$ & $20.13 \pm 0.44$ & $6.72 \pm 0.83$ & $1.46 \pm 0.45$ & $5.70 \pm 0.08$ \\
LSD & 3.62 & 0.55 & 1.65 & 0.47 & 0.22 \\
\hline
\end{tabular}

LSD: Least significant difference

\subsection{Microbiological quality of irradiated goat meat}

The microbial load of goat meat decreased with increasing doses of gamma irradiation treatment (Table 2). Initially and during the 5 weeks of storage, irradiation with 2, 4, and 6 $\mathrm{kGy}$ resulted in lower plate counts in irradiated goat meat samples compared with nonirradiated control samples. Samples irradiated with 4 and $6 \mathrm{kGy}$ had no detectable microorganisms on day $0\left(<1.0 \log ^{10} \mathrm{CFU} \mathrm{g^{-1 }}\right)$ and had consistently low microbial counts thereafter. Others have also reported that irradiation reduced total counts in ground beef with irradiation dose of $3 \mathrm{kGy}$ (CHEN et al., 2007).

Table 2. Effect of gamma irradiation on the bacterial load of goat meat stored at $\left(1-4{ }^{\circ} \mathrm{C}\right)$

\begin{tabular}{|c|c|c|c|c|c|}
\hline Storage period & 0 & 1 & $\begin{array}{c}3 \\
\text { Weeks }\end{array}$ & 4 & 5 \\
\hline & \multicolumn{5}{|c|}{ Total microbial load $\left(\log _{10} \mathrm{CFU} \mathrm{g} \mathrm{g}^{-1}\right)$} \\
\hline $0 \mathrm{kGy}$ & $6.15 \pm 0.24$ & $6.23 \pm 0.26$ & $\mathrm{R}$ & $\mathrm{R}$ & $\mathrm{R}$ \\
\hline $2 \mathrm{kGy}$ & $4.16 \pm 0.65$ & $4.23 \pm 0.13$ & 7. $65 \pm 0.08$ & $\mathrm{R}$ & $\mathrm{R}$ \\
\hline 4 kGy & $<1$ & $2.13 \pm 0.67$ & $2.70 \pm 0.08$ & $7.68 \pm 0.15$ & $\mathrm{R}$ \\
\hline \multirow[t]{2}{*}{$6 \mathrm{kGy}$} & $<1$ & $<1$ & $<1$ & $3.03 \pm 0.14$ & $7.1 \pm 0.19$ \\
\hline & \multicolumn{5}{|c|}{ Total coliforms $\left(\log _{10} \mathrm{CFU} \mathrm{g}^{-1}\right)$} \\
\hline $0 \mathrm{kGy}$ & $3.57 \pm 3.21$ & $4.8 \pm 0.48$ & $\mathrm{R}$ & $\mathrm{R}$ & $\mathrm{R}$ \\
\hline $2 \mathrm{kGy}$ & $<1$ & $<1$ & $<1$ & $\mathrm{R}$ & $\mathrm{R}$ \\
\hline 4 kGy & $<1$ & $<1$ & $<1$ & $<1$ & $\mathrm{R}$ \\
\hline $6 \mathrm{kGy}$ & $<1$ & $<1$ & $<1$ & $<1$ & $<1$ \\
\hline
\end{tabular}

R: Rejected

According to the AL-BACHIR and ZeINOU (2009) formula, which was used in our study as a reference indicator; control samples of goat meat exceeded the acceptance limit of $10^{7} \mathrm{CFU} \mathrm{g}{ }^{-1}$ after one week of storage at $1-4{ }^{\circ} \mathrm{C}$. Samples irradiated with 4 and $6 \mathrm{kGy}$ remained acceptable even after 3 and 4 weeks of storage. Thus, the microbiological shelf-life of goat meat was significantly extended from one week (control) to 4 weeks (samples treated with $6 \mathrm{kGy}$ ). 
The total coliform number in goat meat was $3.57 \log ^{10} \mathrm{CFU} \mathrm{g} \mathrm{g}^{-1}$ at the initial stage and 2, 4 , and $6 \mathrm{kGy}$ of gamma irradiation reduced the population of total coliforms to undetectable level (lower than $1.0 \log ^{10} \mathrm{CFU} \mathrm{g}^{-1}$ ). Some researchers indicated that faecal coliforms were eliminated with $2 \mathrm{kGy}$ irradiation dose (VurAL \& AKsu, 2006).

The radiation doses required to reduce the microorganisms load by one log cycle $\left(\mathrm{D}_{10}\right)$ in goat meat were 294 and 400 Gy for the Salmonella and E. coli, respectively. Jo and coworkers (2004) observed the $\mathrm{D}_{10}$ values of Salmonella Typhimurium and E. coli in marinated beef rib and reported these as 636 and $538 \mathrm{~Gy}$, after gamma irradiation. The $\mathrm{D}_{10}$ values reported by these investigators for Salmonella and E. coli are higher than ours. The small differences are possibly due to the different meat samples and the much higher gamma irradiator energy used in our experiment.

\subsection{Chemical quality of irradiated goat meat}

2.3.1. Total acidity. Regardless of irradiation or storage period, the same total acidity percentages were observed among all samples at weeks $0,1,3,4$, and 5 (Table 3). Previous studies in our lab indicated that no significant differences in total acidity were observed as a result of irradiation of luncheon meat (AL-BACHIR, 2005) and camel meat (AL-BACHIR \& ZEINOU, 2009).

Table 3. Effect of gamma irradiation on total acidity, TBA values, and volatile nitrogen content of goat meat stored at $1-4{ }^{\circ} \mathrm{C}$

\begin{tabular}{|c|c|c|c|c|c|c|}
\hline $\begin{array}{l}\text { Storage period } \\
\text { Treatment }\end{array}$ & 0 & 1 & $\begin{array}{c}3 \\
\text { Weeks }\end{array}$ & 4 & 5 & LSD \\
\hline & \multicolumn{6}{|c|}{ Total acidity (\% lactic acid) } \\
\hline 0 kGy & $0.52 \pm 0.05$ & $0.48 \pm 0.03$ & $\mathrm{R}$ & $\mathrm{R}$ & $\mathrm{R}$ & 0.09 \\
\hline 2 kGy & $0.52 \pm 0.01$ & $0.50 \pm 0.01$ & $0.48 \pm 0.04$ & $\mathrm{R}$ & $\mathrm{R}$ & 0.05 \\
\hline 4 kGy & $0.51 \pm 0.03$ & $0.47 \pm 0.02$ & $0.46 \pm 0.03$ & $0.58 \pm 0.06$ & $\mathrm{R}$ & 0.07 \\
\hline 6 kGy & $0.54 \pm 0.03$ & $0.57 \pm 0.03$ & $0.44 \pm 0.02$ & $0.53 \pm 0.04$ & $0.50 \pm 0.03$ & 0.05 \\
\hline \multirow[t]{2}{*}{ LSD } & 0.05 & 0.05 & 0.06 & 0.12 & - & \\
\hline & \multicolumn{6}{|c|}{ TBA value (ppm) } \\
\hline $0 \mathrm{kGy}$ & $0.17 \pm 0.01$ & - & $\mathrm{R}$ & $\mathrm{R}$ & $\mathrm{R}$ & \\
\hline $2 \mathrm{kGy}$ & $0.18 \pm 0.01$ & $0.16 \pm 0.01$ & $0.25 \pm 0.04$ & $\mathrm{R}$ & $\mathrm{R}$ & 0.048 \\
\hline 4 kGy & $0.20 \pm 0.01$ & $0.22 \pm 0.021$ & $0.31 \pm 0.05$ & $0.76 \pm 0.06$ & $\mathrm{R}$ & 0.076 \\
\hline 6 kGy & $0.21 \pm 0.01$ & $0.26 \pm 0.03$ & $0.34 \pm 0.03$ & $0.52 \pm 0.02$ & $0.48 \pm 0.01$ & 0.36 \\
\hline \multirow[t]{2}{*}{ LSD } & 0.02 & 0.04 & 0.08 & 0.1 & & \\
\hline & \multicolumn{6}{|c|}{ Volatile basic nitrogen (VBN) (ppm) } \\
\hline 0 kGy & $103.7 \pm 13.5$ & $124.3 \pm 11.5$ & $\mathrm{R}$ & $\mathrm{R}$ & $\mathrm{R}$ & 28.44 \\
\hline 2 kGy & $117.3 \pm 8.5$ & $91.3 \pm 8.5$ & $144.3 \pm 1.5$ & $\mathrm{R}$ & $\mathrm{R}$ & 13.99 \\
\hline 4 kGy & $110.0 \pm 3.0$ & $94.3 \pm 11.5$ & $160.7 \pm 10.50$ & $163.7 \pm 7.5$ & $\mathrm{R}$ & 16.52 \\
\hline $6 \mathrm{kGy}$ & $115.7 \pm 1.5$ & $115.7 \pm 11.5$ & $152.0 \pm 9.00$ & $168.7 \pm 1.5$ & $166.3 \pm 19.5$ & 19.90 \\
\hline LSD & 15.35 & 20.40 & 16.05 & 12.28 & - & \\
\hline
\end{tabular}

R: Rejected; LSD: least significant difference 
2.3.2. Lipid oxidation. Data of lipid oxidation for irradiated and non-irradiated fresh meat samples are shown in Table 3. Non-irradiated control samples had significantly lower $(\mathrm{P}<0.05)$ initial (day 0$)$ TBA values $\left(0.17 \mathrm{mg} \mathrm{kg}^{-1}\right)$ than irradiated samples $(0.18,0.20$, and $0.21 \mathrm{mg} \mathrm{kg}^{-1}$ irradiated with doses of 2,4 , and $6 \mathrm{kGy}$, respectively). The TBA values increased with irradiation at day 0 (Table 3 ). This is in agreement with the study of ForMANEK and coworkers (2003), who found that irradiation of aerobically packaged beef or pork increased the oxidative rancidity. As storage time increased, TBA values of irradiated samples increased significantly $(\mathrm{P}<0.05)$. AHN and NAM (2004) also pointed out that overall lipid oxidation of irradiated beef increased with storage time.

2.3.3. Volatile basic nitrogen $V B N$. VBN data for irradiated and non-irradiated fresh meat are shown in Table 3. According to the data obtained, immediately after treatment the value of VBN of irradiated goat meat gamma irradiated with 2, 4, and $6 \mathrm{kGy}$ was slightly higher (117.3, 110.0, and $115.7 \mathrm{ppm}$, respectively) than that of the control (103.7 ppm). These results agree with previous observations on rabbit meat (BADR, 2004) and camel meat (Al-BACHIR \& Zeinou, 2009; FALlah et al., 2010). During storage, the VBN values of samples irradiated with 2 and $4 \mathrm{kGy}$ decreased from 117.3 and $110.0 \mathrm{ppm}$ (day 0) to 91.3 and 94.3 ppm (week 1), respectively, and then increased up to week 2 for samples irradiated with $2 \mathrm{kGy}$ to a value of $144.3 \mathrm{ppm}$, and up to week 3 for samples irradiated with $4 \mathrm{kGy}$ to a value of $163.7 \mathrm{ppm}$. This might be due to the growth of spoilage bacteria, by which some volatile bases were produced (Table 2). The VBN is related to protein breakdown (EGAN et al., 1981) and the observed increase through the storage periods may be attributed to the formation of ammonia or other basic compounds due to microbial activity (BADR, 2004).

2.3.4. Fatty acids. Individual fatty acid (FA) composition of Syrian Jabali goat meat is presented in Table 4. The main fatty acids identified from the goat meat were oleic $\left(\mathrm{C}_{18: 1}\right)$, stearic $\left(\mathrm{C}_{18: 0}\right)$, and palmitic $\left(\mathrm{C}_{16: 0}\right)$ acids, with percentages of $41.55 \%, 25.45 \%$, and $22.24 \%$, respectively. These values are similar to those reported on the muscle fatty acid content of Pakistani Pateri goat (TALPUR et al., 2008). Muscle tissue of the Jabali goats contained an average 51.21 and $48.78 \%$ of saturated fatty acids (SFA) and unsaturated fatty acids (UFA), respectively (Table 4). These figures are in line with those reported elsewhere (TALPUR et al., 2008). The ratio of PUFA/SFA was very low (0.14). These results are similar to those reported for Australian Boer feral goats (0.10-0.30) (WeRDI et al., 2006) and for Pakistani Pateri goat (0.21-0.28) (TALPUR et al., 2008).

Monounsaturated fatty acid (MUFA) content of Jabali goats, averaged $41.55 \%$ of total FA, is in agreement with previous reports (WERDI et al., 2007) for muscle of Australian feral goats $(44.4 \%$ of total FA).

Current recommendations are that PUFA/SFA $(\mathrm{P} / \mathrm{S})$ ratios should be around 0.45 (WEBB et al., 2005). The $\mathrm{P} / \mathrm{S}$ ratio in this study was lower than the recommended ratio, being 0.10 . LEE and co-workers (2008b) reported a higher P/S ratio (0.31) for Boer X Spanish genotype goat.

There are no significant differences on saturated $\left(\mathrm{C}_{10: 0}, \mathrm{C}_{14: 0}, \mathrm{C}_{16: 0}, \mathrm{C}_{17: 0}\right.$, and $\left.\mathrm{C}_{18: 0}\right)$ and unsaturated fatty acids $\left(\mathrm{C}_{18: 1}, \mathrm{C}_{18: 2}\right.$, and $\left.\mathrm{C}_{18: 3}\right)$ between goat meat lipid extracted from irradiated and non-irradiated meat. AlFAIA and co-workers (2007) reported that radiation processing of lamb meat did not affect $(\mathrm{P}>0.05)$ the percentage of any of the analysed fatty acids. 
Table 4. Effect of gamma irradiation on free fatty acids in the lipids of goat meat stored at $1-4{ }^{\circ} \mathrm{C}$

\begin{tabular}{lccccc}
\hline \multicolumn{5}{c}{ Irradiation dose (kGy) } \\
\hline FFA & 0 & 2 & 4 & 6 & LSD \\
\hline $\mathrm{C}_{10: 0}$ & $0.15 \pm 0.02$ & $0.20 \pm 0.05$ & $0.18 \pm 0.01$ & $0.23 \pm 0.02$ & 0.55 \\
$\mathrm{C}_{14: 0}$ & $1.95 \pm 0.03$ & $2.14 \pm 0.17$ & $2.12 \pm 0.03$ & $1.85 \pm 0.10$ & 0.19 \\
$\mathrm{C}_{16: 0}$ & $22.24 \pm 0.33$ & $22.77 \pm 0.57$ & $22.77 \pm 0.59$ & $22.37 \pm 0.19$ & 0.86 \\
$\mathrm{C}_{17: 0}$ & $1.44 \pm 0.07$ & $1.42 \pm 0.05$ & $1.62 \pm 0.03$ & $1.40 \pm 0.003$ & 0.08 \\
$\mathrm{C}_{18: 0}$ & $25.45 \pm 0.44$ & $25.05 \pm 2.99$ & $24.89 \pm 1.20$ & $27.86 \pm 1.06$ & 3.23 \\
$\mathrm{C}_{18: 1}$ & $41.55 \pm 0.41$ & $41.47 \pm 2.92$ & $42.38 \pm 1.33$ & $39.50 \pm 0.59$ & 3.10 \\
$\mathrm{C}_{18: 2}$ & $3.96 \pm 0.34$ & $3.42 \pm 0.41$ & $3.14 \pm 0.36$ & $3.22 \pm 0.20$ & 0.63 \\
$\mathrm{C}_{18: 3}$ & $1.03 \pm 0.06$ & $1.11 \pm 0.06$ & $1.06 \pm 0.11$ & $1.06 \pm 0.01$ & 0.13 \\
Others & $2.24 \pm 0.40$ & $2.42 \pm 0.27$ & $1.84 \pm 0.54$ & $2.53 \pm 0.39$ & 0.77 \\
& & & & 3.86 \\
Saturated (S) & $51.23 \pm 0.47$ & $51.58 \pm 3.47$ & $51.58 \pm 1.79$ & $53.7 \pm 1.162$ & 3.56 \\
Unsaturated (U) & $46.45 \pm 0.66$ & $45.99 \pm 3.29$ & $46.57 \pm 1.57$ & $43.78 \pm 0.78$ & 0.62 \\
Poly-unsaturated (P) & $4.99 \pm 0.39$ & $4.53 \pm 0.39$ & $4.2 \pm 0.30$ & $4.27 \pm 0.19$ & 0.14 \\
U/S & $0.91 \pm 0.02$ & $0.89 \pm 0.13$ & $0.90 \pm 0.06$ & $0.82 \pm 0.033$ & 0.018 \\
P/S & $0.097 \pm 0.008$ & $0.088 \pm 0.014$ & $0.082 \pm 0.009$ & $0.080 \pm 0.005$ & 0.133 \\
$\left(\mathrm{C} 1_{8: 0}+\mathrm{C}_{18: 1}\right) / \mathrm{C}_{16: 0}$ & $3.01 \pm 0.06$ & $2.92 \pm 0.10$ & $2.96 \pm 0.085$ & $3.01 \pm 0.004$ &
\end{tabular}

LSD: Least significant difference

\subsection{Sensory quality of irradiated goat meat}

Sensory testing (Table 5) showed that taste, odour, colour, and texture characteristics of goat meat were unaffected by gamma irradiation treatment. Sensory evaluation scores were basically the same for both irradiated and non-irradiated samples and were acceptable to panelists. A correlation between sensory evaluation and chemical parameters was observed in relation to irradiated goat meat. Previous studies in our lab indicated that no significant differences in sensory quality (taste, odour, colour, and texture) were observed as a result of irradiation $(2,4$, and $6 \mathrm{kGy})$ in luncheon meat (AL-BACHIR, 2005) and camel meat (AL-BACHIR \& ZEINOU, 2009).

Table 5. Effect of gamma irradiation on the sensory properties of goat meat (5 points scale)

\begin{tabular}{lcccc}
\hline Treatment & Texture & Flavour & Colour & Taste \\
\hline $0 \mathrm{kGy}$ & $3.76 \pm 1.33$ & $3.76 \pm 1.23$ & $3.92 \pm 1.41$ & $3.44 \pm 1.50$ \\
$2 \mathrm{kGy}$ & $3.68 \pm 1.18$ & $3.20 \pm 1.19$ & $3.92 \pm 1.19$ & $3.24 \pm 1.62$ \\
$4 \mathrm{kGy}$ & $3.64 \pm 1.29$ & $3.76 \pm 1.09$ & $4.12 \pm 1.09$ & $3.56 \pm 1.37$ \\
$6 \mathrm{kGy}$ & $3.69 \pm 1.20$ & $3.48 \pm 1.23$ & $3.96 \pm 1.41$ & $3.52 \pm 1.69$ \\
LSD & 0.715 & 0.67 & 0.71 & 0.87 \\
\hline
\end{tabular}

Data represent a 5 point scale ranging from 1 (very bad) to 5 (very good) 


\section{Conclusion}

In conclusion, irradiation dose of $6 \mathrm{kGy}$ can be effective to control bacterial spoilage and pathogens in goat meat, through its effectiveness in extending their refrigeration shelf-life from one week (control) to more than 4 weeks (samples treated with $6 \mathrm{kGy}$ ) without any significant effect on the chemical characteristics or sensory quality.

The authors wish to express their deep appreciation to the Director General of the Atomic Energy Commission of Syria and the staff of the division of food irradiation.

\section{References}

AнN, D.U. \& NAM, K.C. (2004): Effects of ascorbic acid and antioxidants on color, lipid oxidation and volatiles of irradiated ground beef. Radiat. Phys. Chem., 71, 149-154.

AL-BACHIR, M. (2005): The irradiation of spices, packaging materials and luncheon meat to improve the storage life of the end products. Int. J. Fd Sci. Technol., 40, 197-204.

AL-BACHIR, M. \& ZEINOU, R. (2009): Effect of gamma irradiation on microbial load and quality characteristics of minced camel meat. Meat Sci., 82, 119-124.

Alfaia, C.M.M., Ribeiro, P.J.L.C., Trigo, M.J.P., Alfaia, A.J.I., Castro, M.L.F., Fontes, C.M.G.A., Bessa, R.J.B. \& Prates, J.A.M. (2007): Irradiation effect on fatty acid composition and conjugated linoleic acid isomers in frozen lamb meat. Meat Sci., 77, 689-695.

A.O.A.C. (1990): Official methods of analysis, 15th ed., Association of Official Analytical Chemists, Washington, DC., pp. 951-960.

BADR, H.M. (2004): Use of irradiation to control food borne pathogens and extend the refrigerated market life of rabbit meat. Meat Sci., 67, 541-548.

Biswas, S., Das, A.K., BanerJee, R. \& Sharma, N. (2007): Effect of electrical stimulation on quality of tender stretched chevon sides. Meat Sci., 75, 332-336.

Chen, Y.J., Zhou, G.H., Zhu. X.D., Xu. X.L., TANG, X.Y. \& GAO, F. (2007): Effect of low dose gamma irradiation on beef quality and fatty acid composition of beef intramuscular lipid. Meat Sci., 75, 423-431.

Egan, H., Kirk, R.S. \& Sawyer, R. (1981): Pearson's chemical analysis of foods, 8th ed, Longman Scientific \& Technical, Essex, UK, p. 185.

FALLAH, A.A., TAJIK, H. \& FARSHID, A.A. (2010): Chemical quality, sensory attributes and ultra structural changes of gamma-irradiated camel meat. J. Muscle Fds, 21, 579-613.

Formanek, Z., Lynch, A., Galvin, K., Farkas, J. \& Kerry, J.P. (2003): Combined effects of irradiation and the use of natural antioxidants on the shelf-life stability of over wrapped minced beef. Meat Sci., 63, 433-440.

Jo, C., Lee, N.Y., Kang, H.J., Shin, D.H. \& Byun, M.W. (2004): Inactivation of food- borne pathogens in marinated beef rib by ionizing radiation. Fd Microbiol., 21, 543-548.

Kanatt, S.R., Chander, R. \& Sharma, A. (2007): Antioxidant potential of mint (Mentha spicata L.) in radiationprocessed lamb meat. Fd Chem., 100, 451-458.

LeE, J.H., Kannan, G., Eega, K.R., Kouakou, B. \& Getz, W.R. (2008A): Nutritional and quality characteristics of meat from goats and lambs finished under identical dietary regime. Small Ruminant Res., 74, 255-259.

Lee, J.H., Kouakou, B. \& Kannan, G. (2008в): Chemical composition and quality characteristics of chevon from goats fed three different post- weaning diets. Small Ruminant Res., 75, 177-184.

Modi, V.K., Sakhare, P.Z., Sachindra, N.M., \& Mahendrakar, N.S. (2008): Changes in quality of minced meat from goat due to gamma irradiation. J. Muscle Fds, 19, 430-442.

PARRY, S.J. (1991): Activation spectrometry in chemical analysis, John Wiley and Sons, New York, 243 pages.

SNedecor, G. \& Cochran, W. (1988): Statistical methods. The Iowa State University Press, Ames, Iowa, 503 pages.

Sohn, S.H., JANG, A., KIm, J.K., Song, H.P., KIм, J.H., LeE, M. \& Jo, C. (2009): Reduction of irradiation off-odor and lipid oxidation in ground beef by gamma-tocopherol addition and the use of a charcoal pack. Radiat. Phys. Chem., 78, 141-146. 
Talpur F.N., Bhanger, M.I. \& Sherazi, S.T. (2008): Intramuscular fatty acid profile of longissimus dorsi and semitendinosus muscle from Pateri goats fed under traditional feeding system of Sindh, Pakistan. Meat Sci., 80, 819-822.

Vural, A. \& AKsu, H. (2006): Effect of gamma irradiation on microbiological and physico-chemical quality of meatballs. Med. Weterynar, 62, 1011-1015.

Webb, E.C., Casey, N.H. \& Simela, L. (2005): Goat meat quality. Small Ruminant Res., 60, 153-166.

Werdi Pratiwi, N.M., Murray, P.J., Taylor, D.G. \& Zhang, D. (2006): Comparison of breed, slaughter weight and castration on fatty acid profiles in the longissimus thoracic muscle from male Boer and Australian feral goats. Small Ruminant Res., 64, 94-100.

Werdi Pratiwi, N.M., Murray, P.J. \& Taylor, D.G. (2007): Feral goats in Australia: A study on the quality and nutritive value of their meat. Meat Sci., 75, 168-177. 